(С). Ю. Гончарук-Хомин, А. Т. Кенюк, С. І. Крічфалушій, І. Д. Мельничук, I. В. Пензелик

ДВН3 «Ужгородський національний університет»

e-mail: myroslav.goncharuk-khomyn@uzhnu.edu.ua

\title{
Потенційний вплив особливостей дієти на процес остеоінтеграції дентальних імплантатів
}

ІНФОРМАЦІЯ

Надійшла до редакції/Received: 06.05.2021 p.

Ключові слова: дієта; дентальні імплантати; ретроспективний аналіз.

\section{АНОТАЦІЯ}

Резюме. В умовах прогресуючої тенденції щодо поширеності виконання процедури дентальної імплантації, необхідним є урахування потреби в індивідуалізації підходів до стоматологічного лікування та аналіз перспективного впливу сукупності пацієнтасоційованих факторів, що являються складовими прогнозу функціонування встановлених внутрішньокісткових опор. Одними із пацієнтасоційованих параметрів, що характеризується потенційно-значимим впливом на прогноз остеоінтеграції, залишаються особливості метаболізму та дієти, які за даними літератури, можуть бути пов’язані із відповідними змінами у структурі кісткової тканини.

Мета дослідження - проаналізувати особливості потенційного впливу параметрів харчування, дієти та специфіки метаболізму, асоційованої з ними, на процес остеоінтеграції та подальшого функціонування дентальних імплантатів за даними експериментальних, ретроспективних, клінічних та оглядових досліджень.

Матеріали і методи. Дизайн дослідження носив ретроспективний характер $з$ проведенням аналітичного опрацювання даних, відібраних із таргетносформованої вибірки релевантних публікацій. Формування та укомплектування первинної сукупності наукових робіт, що підлягали подальшому опрацюванню згідно з принципами контент-аналізу, проводилося з використанням пошукової системи Google Scholar (https:// scholar.google.com/) та бази даних PubMed (https://pubmed.ncbi.nlm.nih. gov/) із застосуванням відповідних ключових слів («dental implant», «diet», «nutrition», «vitamin», «fat intake», «protein intake») та Mesh-термінів.

Результати досліджень та їх обговорення. В якості цільових для деталізованого контент-аналізу було відібрано 20 наукових публікацій: 3 яких 5 представляли результати оглядів, 10 - результати експериментальних лабораторних досліджень на тваринних моделях, 2 - презентації клінічних випадків, 2 - ретроспективні дослідження, 1 - рандомізоване контрольоване дослідження. Аналіз літературних даних, що стосувалися впливу дієти на стан кісткової тканини щелеп, засвідчив доцільність реалізації моніторингу споживання їжі серед пацієнтів, які проходять стоматологічне лікування, і при цьому характеризуються наявністю різного роду місцевих та системних порушень у структурі кісткової тканини. Крім того, вчасна та адекватна корекція дієти після проведення імплантологічних та пародонтологічних втручань, а також на різних етапах подальшої реабілітації сприяє підвищенню показників інтегрального критерію якості життя стоматологічних пацієнтів. Висновки. За даними експериментальних досліджень зміни ліпідного (перенасичення) та білкового (дефіцит) обміну спровоковані дієтою та харчуванням можна розцінювати як такі, що контрибутивно можуть негативно впливати на процес остеоінтеграції дентальних імплантатів, проте лише за умов урахування тривалості та інтенсивності експозиції провокуючих факторів та індивідуально-детермінованих параметрів метаболізму, а також при застосуванні відповідних специфічних лабораторних та інструментальних методів дослідження. 
Вступ. За даними доступних ретроспективних аналізів та асоційованих літературних оглядів у стоматологічній практиці відмічається зростальна поширеність проведення процедури дентальної імплантації з метою забезпечення умов для подальшої ортопедичної реабілітації пацієнтів із різними формами адентії [1-3]. Така тенденція до зростання кількості проведених імплантологічних втручань пов'язана із впливом низки чинників, основними серед яких можна виокремити наступні: 1) підвищення рівня кваліфікації та практично-орієнтованого навчання лікарів для виконання даного виду маніпуляцій; 2) доступність різних видів імплантологічних систем на ринку України з широким ціновим діапазоном; 3) формування відповідного рівня пропозиції з боку лікарів-стоматологів, базуючись на біологічних перевагах процедури дентальної імплантації, із застосуванням різних видів маркетингових технологій; 4) зростання попиту на процедуру дентальної імплантації з боку пацієнтів, асоційованого із зростальним обсягом їх проінформованості щодо можливостей реабілітації із використанням конструкцій дентальних імплантатів [1, 3].

Однак в умовах прогресуючої тенденції щодо поширеності виконання процедури дентальної імплантації, необхідним є урахування потреби в індивідуалізації підходів до стоматологічного лікування та аналіз перспективного впливу сукупності пацієнтасоційованих факторів, що являються складовими прогнозу функціонування встановлених внутрішньокісткових опор [4-6]. Одним із пацієнтасоційованих параметрів, що характеризується потенційно-значимим впливом на прогноз остеоінтеграції, залишаються особливості метаболізму та дієти, специфічно такої із високим вмістом жирів, яка за даними літератури, може бути пов'язана із відповідними змінами в структурі кісткової тканини [7, 8]. На клітинному рівні умови гіперліпідемії інгібують остеогенну активність, знижують рівень формування зрілих остеобластів, провокують зростання експресії молекулярних маркерів кісткового ремоделювання, асоційовані із диференціацією та активністю остеокластів, що призводить до резорбції кісткової тканини [9].

Вищеперераховані внутрішньокісткові зміни на фоні гіперліпідемії, у свою чергу, можуть відігравати важливу роль для прогнозу функціонування встановлених дентальних імплантатів, оскільки сам процес остеоін- теграції таких пов'язаний із формуванням відповідного інтерфейсу між поверхнею внутрішньокісткової опори та кістковою тканиною, що оточує щелепи, а одним з критеріїв їх успішності є зареєстрований рівень резорбції кісткового гребеня в периімплантатній ділянці [4]. Окрім гіперліпідемії, успішність функціонування дентальних імплантатів може бути пов'язана із впливом ряду інших факторів, прямо чи опосередковано асоційованих із особливостями метаболізму та дієти, відтак вивчення таких та систематизація їх ролі для процесу остеоінтеграції являє собою суттєвий науково-практичний інтерес.

Метою дослідження було проаналізувати особливості потенційного впливу параметрів харчування, дієти та специфіки метаболізму, асоційованої з ними, на процес остеоінтеграції та подальшого функціонування дентальних імплантатів за даними експериментальних, ретроспективних, клінічних та оглядових досліджень.

Матеріали і методи. Дизайн дослідження носив ретроспективний характер із проведенням аналітичного опрацювання даних, відібраних із таргетносформованої вибірки релевантних публікацій. Формування та укомплектування первинної сукупності наукових робіт, що підлягали подальшому опрацюванню згідно з принципами контент-аналізу, проводилося з використанням пошукової системи Google Scholar (https://scholar.google. com/) та бази даних PubMed (https://pubmed. ncbi.nlm.nih.gov/) із застосуванням відповідних ключових слів («dental implant», «diet», «nutrition», «vitamin», «fat intake», "protein intake») та Mesh-термінів (алгоритми пошуку:

(«dental implants» [MeSH Terms] OR («dental» [All Fields] AND «implants» [All Fields]) OR «dental implants» [All Fields] OR («dental» [All Fields] AND «implant» [All Fields]) OR «dental implant» [All Fields]) AND («diet» [MeSH Terms] OR «diet» [All Fields]);

(«dental implants» [MeSH Terms] OR («dental» [All Fields] AND «implants» [All Fields]) OR «dental implants» [All Fields] OR («dental» [All Fields] AND «implant» [All Fields]) OR «dental implant»[All Fields]) AND fat[All Fields]);

(«dental implants» [MeSH Terms] OR («dental» [All Fields] AND «implants» [All Fields]) OR «dental implants» [All Fields] OR («dental» [All Fields] AND «implant» [All Fields]) OR «dental implant» [All Fields]) AND («nutrients» [MeSH Terms] OR «nutrients»[All Fields]); 
(«dental implants» [MeSH Terms] OR («dental» [All Fields] AND «implants» [All Fields]) OR «dental implants» [All Fields] OR («dental» [All Fields] AND «implant»[All Fields]) OR «dental implant» [All Fields]) AND («proteins» [MeSH Terms] OR «proteins» [All Fields] OR "protein» [All Fields]) AND intake[All Fields]);

(«dental implants» [MeSH Terms] OR («dental» [All Fields] AND «implants» [All Fields]) OR «dental implants» [All Fields] OR («dental» [All Fields] AND «implant» [All Fields]) OR «dental implant» [All Fields]) AND ("vitamins» [All Fields] OR «vitamins» [MeSH Terms] OR «vitamins» [All Fields] OR «vitamin» [All Fields]);

(«dental implants» [MeSH Terms] OR («dental» [All Fields] AND «implants» [All Fields]) OR «dental implants» [All Fields] OR («dental» [All Fields] AND «implant» [All Fields]) OR «dental implant» [All Fields]) AND («nutritional status» [MeSH Terms] OR («nutritional» [All Fields] AND «status» [All Fields]) OR «nutritional status» [All Fields] OR «nutrition» [All Fields] OR «nutritional sciences» [MeSH Terms] OR («nutritional» [All Fields] AND «sciences» [All Fields]) OR «nutritional sciences» [All Fields]) [10, 11].

Первинний етап контент-аналізу передбачав відбір цільової вибірки публікацій за результатами опрацювання текстових масивів назв та анотацій усіх ідентифікованих статей 3 подальшим виключенням із кількості таких дублікатів, нерелевантних статей, та таких, котрі безпосередньо не стосувалися поставленої мети дослідження, або ж в яких було висвітлено уже попередньо відібрані для аналізу дані (аналогічного чи ідентичного типу).

Цільовими категоріями контент-аналізу були зміни похідних характеристик, що використовуються для оцінки остеоінтеграції, особливості впливу різних складових дієти та харчування, характеристики дизайнів проведених експериментальних досліджень. Систематизацію та групування даних проводили із застосування прикладного програмного забезпечення Microsoft Excel 2019 (Microsoft Office, 2019) відповідно до методологічних принципів розподілу результатів інтелектуального аналізу текстових масивів даних згідно 3 попередньо сформульованими категоріями контент-аналізу.

Результати досліджень та їх обговорення. В якості цільових для деталізованого контентаналізу було відібрано 20 наукових публікацій: L. Nastri et al. (2020) [7], C. Montalvany-Antonucci et al. (2018) [8], A. Keuroghlian et al. (2015) [9],
S. Dündar et al. (2016) [12], S. Dündar et al. (2020) [13], S. Dündar et al. (2020) [14], S. King et al. (2020) [15], R. Dayer et al. (2007) [16], R. Dayer et al. (2006) [17],G. Dvorak et al. (2012) [18], T. Fretwurst et al. (2016) [9], F. Mangano et al. (2018) [20], F. Javed et al. (2016) [21], X. Li et al. (2018) [22], J. Baldisserotto et al. (2019) [23], S. Pimentel et al. (2016) [24], J. Beaudette et al. (2021) [25], D. Flanagan (2016) [26], B. Lau et al. (2013) [27], S. Najeeb et al. (2016) [28], з яких 5 представляли результати оглядів, 10 - результати експериментальних лабораторних досліджень на тваринних моделях, 2 - презентації клінічних випадків, 2 - ретроспективне дослідження, 1 - рандомізоване контрольоване дослідження.

Переважна сукупність публікацій, опрацьованих у ході проведення ретроспективного аналізу, стосувалася вивчення впливу умов гіперліпідемії на процес остеоінтеграції дентальних імплантатів в експериментальних умовах, а також значимості окремих мікроелементів для формування відповідного функціонального контакту між навколишньою кістковою тканиною та поверхнею внутрішньокісткових опор.

В експериментальному дослідженні на тваринній моделі Dundar (2016) не вдалось встановити значимого впливу дієти 3 високим вмістом жирів на гістоморфометричні зміни контакту між дентальним імплантатом та навколшньою кістковою тканиною (boneimplant contact - BIC) [12]. При цьому автори також відмітили, що отримані результати можуть бути пов'язані з недостатньою тривалістю дії чинника (дієти із високим вмістом жирів) протягом 3 місяців спостереження, оскільки у тварин групи дослідження та групи контролю (нормальна дієта) не спостерігалося також жодних статистично значущих відмінностей щодо зареєстрованих рівнів глюкози, тригліцеридів та АЛТ [12]. У 2020 р. дослідники повторили аналогічний експеримент із більш тривалим часом моніторингу в 6 місяців, проте за умов аналогічної експозиції дієти із високим вмістом жирів (3 місяці) [13]. У ході даного дослідження вдалось встановити, що в умовах тваринної моделі експозиція мишей дієті з високим вмістом жирів упродовж 90 днів, починаючи з другого дня після імплантації у ділянці стегнової кістки, не сприяла статистично вираженому зниженню показника контакту кісткової тканини із поверхнею імплантату, проте провокувала зниження показника виповненості периімплантатної ділянки кістко- 
вою тканиною порівняно з групою контролю $((43,86 \pm 5,61) \%$ проти $(55,29 \pm 11,09) \%)$ [13]. Супровідно зареєстрований значимо вищий рівень тригліцеридів у дослідній групі міг також свідчити про те, що механізм впливу перенасиченої жирами дієти на процес остеоінтеграції є комплексним та реалізується за рахунок декількох шляхів, включаючи метаболізм жиру в крові. У ще одному дослідженні Dundar et al. (2020) не вдалось виявити статистично доведеного негативного впливу дієти із високим вмістом жирів не тільки на площу контакту кісткової тканини та поверхні імплантатів, але й на щільність кісткової тканини великогомілкової кістки (в якій проводилася імплантація) при провокаційному типі вигодовування тварин за три місяців до та три місяці після імплантації [14].

В іншому експериментальному дослідженні на тваринній моделі з вивченням особливостей остеоінтеграції дентальних імплантатів, встановлених атеросклеротично-схильним мишам, було визначено, що дієта із високим вмістом жирів все ж може компроментувати прогноз функціонування внутрішньокісткових опор через 4 та 8 тижнів спостереження за змінами показників контакту 3 кістковою тканиною [9]. Аналогічні дані були отримані при аналізі результатів push-in-тесту: для деструкції інтерфейсу з'єднання між імплантатом та кістковою тканиною була порівняно нижча сила тиску у випадках дослідження конструкцій, встановлених тваринам, які вигодовувались дієтою 3 високим вмістом жирів [9]. Особливість дослідження Keuroghlian et al. (2015) полягала у тому, що експозиція до стресового чинника (дієти із високим вмістом жирів) була забезпечена за 12 тижнів до імплантації та відповідно продовжувалась через 4 та 8 тижнів опісля [9]. На відміну від результатів, отриманих у дослідженні Dundar et al. у 2016 р. [12], така тривала дія провокуючого чинника в результаті також була асоційована із статистично вищими рівнями холестерину та тригліцеридів через 8 тижнів спостереження у групі порівняння проти групи контролю [9].

Дослідження проведене на аналогічній тваринній моделі дозволило виявити, що незалежно від того, чи проводилася установка дентальних імплантатів до моменту експозиції дієті перенасиченої жирами та фруктозою, чи уже на тлі тривалості такої протягом 6 тижнів, даний тип вигодовування дослідних тварин провокував зниження величини кон- такту між кістковою тканиною та поверхнею титанових опор, котре було статистично підтвердженим (незважаючи на те, що у групі експозиції до специфічної дієти, тривалість перебування імплантату в кістковій тканині була на 4 тижні довшою) [15]. Аналогічні зміни також були відмічені при аналізі показників pull-out-тесту на вилучення дентальних імплантатів: у групах тварин, яких вигодовували дієтою, перенасиченою жирами та фруктозою, незалежно від терміну початку вигодовування (до та через 4 тижні після встановлення внутрішньокісткових опор), величина такої сили сягала 71,21-82,03 Н, разом з тим, як у групі контролю їі значення сягало 108,64 Н через один і той самий час перебування імплантатів у кістковій тканині [19]. Статистично нижчими у групі дослідження також виявилися гістоморфометричні показники мінеральної апозиції та співвідношення рівня формування кістки до площі кісткової поверхні. Автори інтерпретували отримані результати як перші, що стосувалися дослідження дієтоіндукованих змін мікроархітектури трабекулярної тканини в периімплантатній ділянці [15]. Таким чином, дієта перенасичена жировими складовими та фруктозою, може бути інтерпретована як потенційний фактор погіршення прогнозу функціонування дентальних імплантатів незалежно від початку впливу такої після чи до проведення процедури дентальної імплантації у розрізі ризику відстроченої (пізньої) втрати інтраосальних опор [15].

Частково вища остеокластична активність під впливом експозиції дієти із високим вмістом жирів може бути пов'язана із виділенням макрофагами $з$ жирової тканини прозапальних цитокінів типу інтерлейкіну-1 та фактора некрозу пухлин у кровоносне русло; вищим рівнем експресії RANKL безпосередньо у кісткову тканину; та зниженням рівня протиостеокластичного інтерлейкіну-10.

У ході аналізу специфіки проведення експериментів 3 цільовим вивченням аспектів та результатів дентальної імплантації на тваринних моделях було визначено, що дослідження впливу дієти із високим вмістом жирів на процес остеоінтеграції при встановленні інтраосальних опор у стегнову кістку мишей характеризуються наступними особливостями, які повинні бути враховані при інтерпретації даних: 1) ремоделювання у структурі стегнових кісток мишей не повністю аналогічне так званому гаверсовому 
ремоделюванню, характерному для кісткової тканини щелеп; 2) стегнова кістка характеризується наявністю відносно великих кістковомозкових просторів, відтак рівень ремоделювання у її структурі відносно менший, аніж в кістковій тканині щелеп; 3) тваринна модель із встановленням імплантатів у стегнову кістку обмежує можливості щодо імітації функціонального навантаження, яке в клінічних умов таргетно передбачено в ході реабілітації.

Дослідницька імітаційна модель ізокалорійної дієти дефіцитної відносно вмісту білків дозволила констатувати негативний вплив такої на особливість формування функціонального з'єднання між поверхнею імплантату та навколишньою кістковою тканиною на 29 \% порівняно з групою контролю [16]. У пізнішому дослідженні Dayer et al. (2007) було встановлено, що протеїн-дефіцитна дієта із редукцією мінімально-необхідного обсягу споживання білків на 50 \% провокує послаблення сили з'єднання між імплантатом та навколишньою кістковою тканиною на 43 та 42 \% через 6 та 8 місяців експозиції даному типу вигодовування відповідно [17]. При цьому також спостерігалося статистично значиме зниження величини контакту між кісткою та встановленою опорою за даними гістоморфометричного дослідження, що також супроводжувалося зміною патерну архітектоніки за даними індексу моделі структури до менш наповненого на одиницю об'єму [17].

На дослідній тваринній моделі Dvorak et al. (2011) довели, що в умовах дефіциту вітаміну D відновлення його постачання в організм сприяє покращенню параметрів контакту кісткової тканини 3 поверхнею імплантату в кортикальній частині, разом 3 тим, як між групами контролю та дослідження не було відмічено значимих відмінностей у структурі губчастої складової (різниця показників мінеральної апозиції також виявилась незначимою) [18]. У ряді презентацій клінічних випадків було представлено негативний потенційний вплив дефіциту вітаміну D на прогноз функціонування дентальних імплантатів, який вдалось оптимізувати та вирішити проблему із ранньою втратою імплантатів за рахунок відповідного мікроелементного забезпечення [19].

У рамках ретроспективного дослідження не вдалось статистично підтвердити, що зниження рівня вітаміну D у сироватці крові асоційовано із зростанням показника ранньої втрати дентальних імплантатів, хоча загальновиражений тренд до такого типу зворотних співвідношень був помічений при порівнянні рівнів поширеності ранньої втрати імплантатів у осіб із зареєстрованою концентрацією вітаміну менше 10 нг/мл $(11,1 \%)$ та в осіб із показником більше ніж 30 нг/мл [20].

У систематичному огляді проспективних in vivo досліджень було відмічено, що доповнення дієти щурів, як суб’єктів досліджуваної моделі, за рахунок вітаміну $\mathrm{D}_{3}$ сприяє покращенню формування контакту між кістковою тканиною та поверхнею встановленого імплантату, а також зростанню тенденції до формування нової кісткової тканини в периімплантатній ділянці за даними гістологічного аналізу, 3D-мікрокомп’ютерної томографії, гістоморфометрії та скануючої електронної мікроскопії [21]. При цьому автори також підкреслили необхідність перевірки гіпотези щодо позитивного впливу $\mathrm{D}_{3}$-вітамінозбагаченої дієти на процес остеінтеграції за умов невідповідного рівня гігієни ротової порожнини, серед пацієнтів старшого віку та при наявності шкідливої звички тютюнокуріння; на думку дослідників, дані фактори потенційно можуть нівелювати ефект вітаміну $\mathrm{D}_{3}$ відносно змін кісткової тканини в периімплантатній ділянці [21].

Застосування добавок вітаміну С сприяло покращенню загоєння рани після встановлення дентальних імплантатів у пацієнтів 3 одномоментно проведеною аугментацією та у пацієнтів із наявною патологією пародонта, проте ніяк не впливало на вираження больового симптому в післяопераційний період [22]. У групі пацієнтів, яким не проводилось суміжної аугментації, та в яких не було зареєстровано ознак пародонтиту, додаткове споживання вітаміну С не сприяло оптимізації процесу загоєння рани [22].

Дієта, збагачена вмістом солі за рахунок додавання до звичного корму фізіологічного розчину за даними дослідної тваринної моделі, не впливала на зміни площі остеоінтеграції дентальних імплантатів у період 2 та 4 місяців спостереження [23].

При відсутності супутніх метаболічно-дефіцитних станів збагачення дієти комплексом мікроелементів та мінералів не сприяло статистично вираженому покращенню якості контакту між навколишньою кістковою тканиною та поверхнею імплантатів за даними мікрокомп’ютерної томографії та згідно 3 
отриманими показниками біомеханічної ретенції (визначених за методом дії зворотного торку) в сформованій дослідній тваринній моделі [24].

В об'єднуючому огляді 19 досліджень, присвячених вивченню впливу мікронутрієнтів та харчових добавок на процес остеоінтеграції дентальних імплантатів, Nastri et al. (2020) констатували дефіцит таких даних для формулювання однозначних висновків, незважаючи на те, що стосовно певних складових (наприклад вітаміну D) були відмічені певні специфічні залежності [7]. Актуальність дослідження ролі мікронутрієнтів та харчових добавок на процес остеоінтеграції обгрунтована тим, що вони потенційно можуть брати участь у загоєнні тканин у периімплантатній ділянці, відновленні кісткової тканини та стабілізації периімплантатної ділянки в цілому, хоча досі неповністю вирішеним залишається питання дозування таких середників [7]. Дослідники також виявили, що значна кількість дослідних мікроаліментарних складових не включена до реєстру «Register on nutrition and health claims for foods», у структурі якого експертна комісія виділила 18, котрі характеризуються потенційний впливом на стан кісток та зубів [7]. Крім того, при урахуванні впливу різних дієтичних добавок на зміни в структурі тканин пародонта після проведення різного роду хірургічних маніпуляцій Beaudette et al. (2021) відмітили, що близько 64,7 \% пацієнтів ще до проведення будь-яких ятрогенних втручань споживають різного роду дієтичні добавки в якості рутинного адитиву до звичної дієти [25]. Відтак для встановлення ролі таких на процес остеоінтеграції та загоєння необхідно встановити їх значимість на початковому рівні функціонування структур зубощелепного апарату до моменту нанесення контрольованої хірургічної травми.

У 2016 p. D. Flanagan описав клінічний випадок, у якому продемонстрував перелом імплантату під впливом довготривалого циклічного неаксіального надмірного навантаження, розвиток якого частково був пов'язаний із споживанням дієти зі значним вмістом твердої їжі [26]. Автор повною мірою проаналізував вплив і суміжних факторів, зокрема парафункціональних звичок, сили накушування, особливостей оклюзії, співвідношення коронка/імплантат, якості та кількості кісткової тканини, і прийшов до висновку, що споживання твердої їжі може розглядати- ся у якості контрибутивного чинника, який в сукупності з іншими факторами опосередковано сприяв поступовій компрометації біомеханічних умов функціонування незнімної ортопедичної конструкції на внутрішньокістковій титановій опорі [26].

Перед проведенням пародонтологічних та імплантологічних втручань Lau et al. (2013) рекомендують враховувати початковий харчовий статус пацієнта та потенційну необхідність його підвищення у післяопераційний період, а також основні харчові звички та уподобання [27]. На думку авторів, після проведення хірургічних маніпуляцій у ділянці щелеп необхідно враховувати обсяг споживання їжі (рівень такого може зростати в період загоєння рани 3 метою підтримання гомеостазу), потребу в забезпеченні легкості споживання їжі (з мінімізацією больових відчуттів та дискомфорту), відповідну смаковість іжі, частоту та обсяг прийому їжі (кількість порцій протягом дня може зростати при зменшенні обсягу кожної окремої порції), простоту в приготуванні та достатній обсяг споживання рідини [27]. Дані рекомендації сформулювали автори у формі практичних рекомендацій, з якими можна ознайомитися у відповідній публікацій від 2013 р. [27].

Результати аналізу літературних даних щодо впливу дієти на стан кісткової тканини щелеп засвідчили доцільність реалізації моніторингу споживання їжі серед пацієнтів, які проходять стоматологічне лікування, і при цьому характеризуються наявністю різного роду місцевих та системних порушень у структурі кісткової тканини [8]. Крім того, вчасна та адекватна корекція дієти після проведення імплантологічного та пародонтологічного лікування, а також на різних етапах подальшої реабілітації сприяє підвищенню показників інтегрального критерію якості життя стоматологічних пацієнтів [28].

Висновки. У результаті проведеного аналізу з урахуванням усіх обмежень, пов’язаних із ретроспективним дизайном даного дослідження та особливостями відбору відповідних публікацій для детального опрацювання, можна резюмувати, що особливості дієти та харчування, а також асоційовані $з$ ними метаболічні зміни, можуть бути інтерпретовані в якості факторів, що характеризуються потенційним впливом на процес остеоінтеграції, проте остаточна роль таких повинна бути доведена в ході подальших протоколь- 
но-організованих досліджень проспективного характеру. При інтерпретації даних, що були отримані в результаті проведення експериментів на тваринних моделях, необхідно враховувати специфіку реалізації таких в розрізі відмінностей щодо параметрів кісткової тканини різної локалізації та обмеження повноцінної можливості імітації функціонального навантаження, що передбачено протоколом реабілітації з опорою на дентальних імплантатах. Очевидно, що за даними експериментальних досліджень зміни ліпідного (перенасичення) та білкового (дефіцит) обмінів, спровоковані дієтою та харчуванням, можна розцінювати як такі, що контрибутивно можуть негативно впливати на процес остеоін- теграції дентальних імплантатів, проте лише за умов урахування тривалості та інтенсивності експозиції провокуючих факторів, та індивідуально-детермінованих параметрів метаболізму, а також при застосуванні відповідних специфічних лабораторних та iнструментальних методів дослідження. Для вивчення ролі вітамінів та мікроелементів на процес остеоінтеграції необхідно встановити їх первинну значимість на початковому рівні функціонування структур зубощелепного апарату до моменту нанесення контрольованої хірургічної травми та встановлення титанової опори, оскільки більше половини пацієнтів споживають різного роду харчові добавки в якості адитивів до звичного раціону.

\section{(М. Ю. Гончарук-Хомин, А. Т. Кенюк, С. И. Крічфалуший, И. Д. Мельничук, И. В. Пензелик}

ГВУЗ «Ужгородский национальный университет»

\section{Потенциальное влияние особенностей диеты на процесс остеоинтеграции дентальных имплантатов}

Резюме. В условиях прогрессирующей тенденции распространенности выполнения процедуры дентальной имплантации, необходимым является учет потребности в индивидуализации подходов к стоматологическому лечению, и анализ перспективного влияния совокупности пациентассоциированных факторов, которые являются составляющими прогноза функционирования установленных внутрикостных опор. Одними из пациентассоциированных параметров, характеризующимися потенциально значимым влиянием на прогноз остеоинтеграции, остаются особенности метаболизма и диеты, которые, по данным литературы, могут быть связаны с соответствующими изменениями в структуре костной ткани.

Цель исследования - проанализировать особенности потенциального влияния параметров питания, диеты и ассоциированной с ними специфики метаболизма на процесс остеоинтеграции и дальнейшего функционирования дентальных имплантатов по данным экспериментальных, ретроспективных, клинических и обзорных исследований.

Материалы и методы. Дизайн исследования носил ретроспективный характер с проведением аналитической обработки данных отобранных из таргетносформированной выборки релевантных публикаций. Формирование и укомплектование первичной совокупности научных работ, подлежащих дальнейшей обработке согласно принципам контент-анализа, проводилось с использованием поисковой системы Google Scholar (https://scholar.google.com/) и базы данных PubMed (https: //pubmed.ncbi. nlm.nih.gov/) с применением соответствующих ключевых слов («dental implant», «diet», «nutrition», «vitamin», «fat intake», «protein intake») и Mesh-терминов.

Результаты исследований и их обсуждение. В качестве целевых для детального контент-анализа было отобрано 20 научных публикаций: из них 5 представляли результаты осмотров, 10 - результаты экспериментальных лабораторных исследований на животных моделях, 2 - презентации клинических случаев, 2 - ретроспективные исследования, 1 - рандомизированное контролируемое исследование. Результаты анализу литературных данных относительно влияния диеты на состояние костной ткани челюстей показал целесообразность реализации мониторинга потребления пищи среди пациентов, которые проходят стоматологическое лечение, и при этом характеризуются наличием разного рода местных и системных нарушений в структуре костной ткани. Кроме того, своевременная и адекватная коррекция диеты после проведения имплантологического и пародонтологического лечения, а также на различных этапах последующей реабилитации способствует повышению показателей интегрального критерия качества жизни стоматологических пациентов.

Выводы. По данным экспериментальных исследований изменения липидного (перенасыщение) и белкового (дефицит) обмена спровоцированы диетой и питанием можно расценивать как такие, 


\section{Хірургічна стоматологія}

которые контрибутивно могут негативно влиять на процесс остеоинтеграции дентальных имплантатов, однако лишь при условии учета продолжительности и интенсивности экспозиции провоцирующих факторов, и индивидуально детерминированных параметров метаболизма, а также при применении соответствующих специфических лабораторных и инструментальных методов исследования.

Ключевые слова: диета; дентальные имплантаты; ретроспективный анализ.

(C). Yu. Goncharuk-Khomyn, A. T. Keniuk, S. I. Krichfalushij, I.D. Melnychuk, I. V. Penzelyk

SHEI "Uzhhorod National University"

\section{Potential influence of dietary features on the process of dental implants osseointegration}

Summary. In the context of a progressive trend within the prevalence of dental implantation procedures, it is necessary to take into account the need for individualization of dental treatment approaches, and for analysis of prospective influence regarding a set of patient-associated factors, which are the components of the functional prognosis of placed intraosseous supports. Ones of the patient-associated parameters, characterized by a potentially significant impact on the osseointegration prognosis, are the features of metabolism and diet, which according to the literature may be associated with corresponding changes in bone structure.

The aim of the study - to analyze the features of the potential impact of nutrition, diet and associated metabolic specifics on the process of osseointegration and subsequent functioning of dental implants according to results obtained in experimental, retrospective, clinical and review studies.

Materials and Methods. The design of the study was retrospective in nature with the analytical processing of data selected from a targeted sample of relevant publications. The formation and completion of the initial set of scientific papers, which were subject to further processing according to the principles of content analysis, was carried out using the Google Scholar search engine (https://scholar.google.com/) and the PubMed database (https: //pubmed.ncbi). nlm.nih.gov/) by the relevant keywords (“dental implant”, “diet”, "nutrition”, "vitamin”, "fat intake”, "protein intake”) and corresponding Mesh terms.

Results and Discussion. 20 scientific publications were selected as targets for detailed content analysis: 5 of them presented the results of reviews, 10 - the results of experimental laboratory studies on animal models, 2 - presentations of clinical cases, 2 - retrospective studies, 1 - randomized controlled trial. Analysis of literature data related with the impact of diet on the condition of the bone tissue of the jaws showed the feasibility of monitoring food intake among patients undergoing dental treatment, who is also characterized by presence of various local and systemic disorders in bone structure. In addition, timely and adequate correction of the diet after implant and periodontal treatment, as well as at the various stages of subsequent rehabilitation helps to improve the values of integrated quality of life criteria among dental patients.

Conclusions. According to the experimental studies, changes in lipid (supersaturation) and protein (deficiency) metabolism provoked by diet and nutrition can be interpreted as contributing to the process of osseointegration of dental implants, but only under considering the duration and intensity of exposure to provoking factors, and patient-determined parameters of metabolism, as well as the use of appropriate specific laboratory and instrumental research methods.

Key words: diet; dental implants; retrospective analysis.

\section{СПИСОК ЛІТЕРАТУРИ}

1. Trends in dental implant use in the US, 1999-2016, and projections to 2026 / H. W. Elani, J. R. Starr, J. D. Da Silva [et al.] // Journal of dental research. -2018. - Vol. 97 (13). - P. 1424-1430.

2. Current trends of the choice and processing of materials for dental implantation / I. V. Maiborodin, A. A. Shevela, M. S. Toder [et al.] // Stomatologiia. - 2018. - Vol.1; 97 (4). - P. 68-76.

3. Current trends in dental implants / L. Gaviria, J. P. Salcido, T.Guda [et al.] // Journal of the Korean
Association of Oral and Maxillofacial Surgeons. - 2014. - Vol. 40 (2). - P. 50-60.

4. M. Goncharuk-Khomyn. Evaluation of peri-implant bone reduction levels from superimposition perspective: pilot study among Ukrainian implantology practice / M. Goncharuk-Khomyn, A. Keniuk //Pesquisa Brasileira em Odontopediatria e Clinica Integrada. - 2018. Vol. 15; 18 (1). - P. 3856.

5. Data Analysis on the Cluster Phenomenon of Dental Implants Loss / M. Ю. Гончарук-Хомин, А. Т. Кенюк 
[та ін.] // Імплантологія. Пародонтологія. Остеологія. - 2018. - № (2). - C.41-46.

6. Prognosis of possible implant loss after immediate placement by the laboratorial blood analysis and evaluation of intraoperatively derived bone samples / A. Potapchuk, V. Rusyn, M. Goncharuk-Khomyn [et al.] // Journal of International Dental and Medical Research. 2019. - Vol. 12 (1). - P. 143 -150.

7. Do Dietary Supplements and Nutraceuticals Have Effects on Dental Implant Osseointegration? / L. Nastri, A. Moretti, S. Migliaccio [et al.] // A Scoping Review. Nutrients. - 2020. - Vol. 12 (1). - P. 268.

8. Diet versus jaw bones: Lessons from experimental models and potential clinical implications / C. C. Montalvany-Antonucci, M. C. Zicker, M. C. Oliveira [et al.] // Nutrition. - 2018. - Vol. 1; 45. - P. 59-67.

9. The effects of hyperlipidemia on implant osseointegration in the mouse femur / A. Keuroghlian, A. D. Barroso, G. Kirikian [et al.] // Journal of Oral Implantology. - 2015. - Vol. 41(2). - P. 7-11.

10. Walters W. H. Google Scholar search performance: Comparative recall and precision. Portal / W. H. Walters // Libraries and the Academy. - 2009. - Vol. 9 (1). - P. 5-24.

11. Richter R. R. Using MeSH (medical subject headings) to enhance PubMed search strategies for evidencebased practice in physical therapy / R. R. Richter, T. M. Austin // Phys. Ther. - 2012. - Vol. 92 (1). - P. 124-132. 12. The effects of high-fat diet on implant osseointegration: an experimental study / S. Dündar, F. Yaman, M. F. Ozupek [et al.] // Journal of the Korean Association of Oral and Maxillofacial Surgeons. - 2016. Vol. 42 (4). - P. 187-192.

13. Does high fat diet effect the bone-implant connection?/ S. Dundar, A. Bozoglan, K. Sahin [et al.] // Bratislavske Lekarske Listy. - 2020. - Vol. 1; 121 (6). - P. 450-454.

14. Effects of restraint stress and high-fat diet on osseointegration of titanium implants: an experimental study / S. Dundar, A. Bozoglan, O. Bulmus [et al.] // Brazilian oral research. - 2020. - Vol. 34. - P. e008.

15. A diet high in fat and fructose adversely affects osseointegration of titanium implants in rats / S. King, C. Baptiston Tanaka, D. Ross [et al.] // Clinical and experimental dental research. - 2020. - Vol. 6 (1). P. 107-116.

16. Defective implant osseointegration under protein undernutrition: prevention by PTH or pamidronate / R. Dayer, I. Badoud, R. Rizzoli [et al.] // Journal of Bone and Mineral Research. - 2007. - Vol. 22 (10). - P. 1526-1533. 17. Low protein intake is associated with impaired titanium implant osseointegration / R. Dayer, R. Rizzoli,

\section{REFERENCES}

1. Elani, H.W., Starr, J.R., Da Silva, J.D. \& Gallucci, G.O. (2018). Trends in dental implant use in the US, 1999-2016, and projections to 2026. Journal of Dental Research., 97 (13), 1424-1430.

2. Maiborodin, I.V., Shevela, A.A., Toder, M.S., \& Shevela, A.I. (2018). Current trends of the choice and processing of materials for dental implantation. Stomatologiia.,97 (4), 68-76.
A. Kaelin [et al.] // Journal of Bone and Mineral Research. - 2006. - Vol. 21 (2). - P.258-264.

18. Impact of dietary vitamin D on osseointegration in the ovariectomized rat / G. Dvorak, A. Fügl, G. Watzek [et al.] // Clinical oral implants research. - 2012. - Vol. 23 (11). - P. 1308-1313.

19. Vitamin D deficiency in early implant failure: two case reports / T. Fretwurst, S. Grunert, J. P. Woelber [et al.] // International journal of implant dentistry. - 2016. - Vol. 2 (1). - P. 1-6.

20. Low serum vitamin D and early dental implant failure: Is there a connection? A retrospective clinical study on 1740 implants placed in 885 patients / F. G. Mangano, S. G. Oskouei, A. Paz [et al.] //Journal of dental research, dental clinics, dental prospects. -2018. - Vol. 12 (3). - P. 174-182.

21. Efficacy of vitamin D3 supplementation on osseointegration of implants / F. Javed, H. Malmstrom, S. V. Kellesarian [et al.] // Implant dentistry. - 2016. Vol. 1; 25 (2). - P. 281-287.

22. Role of vitamin C in wound healing after dental implant surgery in patients treated with bone grafts and patients with chronic periodontitis / X. Li, L. Tang, Y. F. Lin [et al.] // Clinical implant dentistry and related research. - 2018. - Vol. 20 ( 5). - P. 793-798.

23. Baldisserotto J.. The Influence of Dietary Salt on the Osseointegration of Implants in Aging Rats / J. Baldisserotto, D. M. Padilha, J. M. Amenábar // International archives of otorhinolaryngology. - 2019. - Vol. 23 (4). - P. 427-432.

24. Impact of micronutrients supplementation on bone repair around implants: microCT and counter-torque analysis in rats / S. P. Pimentel, R. C. Casarin, F. V. Ribeiro [et al.] // Journal of Applied Oral Science. - 2016. - Vol. 24 (1). - P. 45-51.

25. Patients undergoing periodontal procedures commonly use dietary supplements: A consideration in the design of intervention trials / J. R. Beaudette, P. C. Fritz, P. J. Sullivan [et al.]// Clinical and Experimental Dental Research. - 2021. - Vol. 7 (1). - P. 123-128.

26. Flanagan D. Diet and implant complications / D. Flanagan // Journal of Oral Implantology. - 2016. Vol. 42 (3). - P. 305-310.

27. Lau B. Y. Dietary strategies to optimize wound healing after periodontal and dental implant surgery: an evidence-based review / B. Y. Lau, B. D. Johnston, P. C. Fritz [et al.] // The open dentistry journal. - 2013. Vol. 7. - P. 36-46.

28. The role of nutrition in periodontal health: an update / S. Najeeb, M. S. Zafar, Z. Khurshid [et al.] // Nutrients. - 2016. - Vol. 8 (9). - P. 530.

3. Gaviria, L., Salcido, J.P., Guda, T., \& Ong, J.L. (2014). Current trends in dental implants. Journal of the Korean Association of Oral and Maxillofacial Surgeons., 40 (2), 50-60.

4. Goncharuk-Khomyn, M., \& Keniuk, A. (2018). Evaluation of peri-implant bone reduction levels from superimposition perspective: pilot study among Ukrainian implantology practice. Pesquisa Brasileira em Odontopediatria e Clinica Integrada., 18 (1), 3856. 
5. Honcharuk-Khomyn, M.Yu., Keniuk, A.T.., Rusyn, V.V., Melnychuk, I.D., \& Foros, A.I. (2018). Data Analysis on the Cluster Phenomenon of Dental Implants Loss. Implantolohia Parodontolohia Osteolohia - Impantology Parodontology Osteology, 2, 41-46.

6. Anatoliy, P., Vitaliy, R., Myroslav, G.K., \& Victoria, H. (2019). Prognosis of possible implant loss after immediate placement by the laboratorial blood analysis and evaluation of intraoperatively derived bone samples. Journal of International Dental and Medical Research., 12 (1), 143-150.

7. Nastri, L., Moretti, A., Migliaccio, S., Paoletta, M., Annunziata, M., Liguori, S., Toro, G., Bianco, M., Cecoro, G., Guida, L., \& Iolascon, G. (2020). Do Dietary Supplements and Nutraceuticals Have Effects on Dental Implant Osseointegration? A Scoping Review. Nutrients., 12(1), 268.

8. Montalvany-Antonucci, C.C., Zicker, M.C., Oliveira, M.C., Macari, S., Madeira, M.F., Andrade, Jr.I., Ferreira, A.V., \& Silva, T.A. (2018). Diet versus jaw bones: Lessons from experimental models and potential clinical implications. Nutrition. 45, 59-67.

9. Keuroghlian, A., Barroso, A.D., Kirikian, G., Bezouglaia, O., Tintut, Y., Tetradis, S., Moy, P., Pirih, F., \& Aghaloo, T. (2015). The effects of hyperlipidemia on implant osseointegration in the mouse femur. Journal of Oral Implantology., 41(2), 7-11.

10. Walters, W.H. (2009). Google Scholar search performance: Comparative recall and precision. Portal. Libraries and the Academy, 9 (1), 5-24.

11. Richter, R.R., \& Austin, T.M. (2012). Using MeSH (medical subject headings) to enhance PubMed search strategies for evidence-based practice in physical therapy. Phys. Ther., 92 (1), 124-132.

12. Dündar, S., Yaman, F., Ozupek, M.F., Saybak, A., Gul, M., Asutay, F., Kirtay, M., \& Ozercan, I.H. (2016). The effects of high-fat diet on implant osseointegration: an experimental study. Journal of the Korean Association of Oral and Maxillofacial Surgeons. 42 (4), 187-192.

13. Dundar, S., Bozoglan, A., Sahin, K., Balci, T.A., Kirtay, M., Bozoglan, M.Y., \& Calisir, M. (2020). Does high fat diet effect the bone-implant connection? Bratislavske Lekarske Listy., 121(6), 450-454.

14. Dundar, S., Bozoglan, A., Bulmus, O., Tekin, S., Yildirim, T.T., Kirtay, M., Toy, V.E., Gul, M., \& Bozoglan, M.Y. (2020). Effects of restraint stress and high-fat diet on osseointegration of titanium implants: an experimental study. Brazilian Oral Research., 34, e008.

15. King, S., Baptiston Tanaka, C., Ross, D., Kruzic, J.J., Levinger, I., Klineberg, I., \& Brennan $\square$ Speranza, T.C. (2020). A diet high in fat and fructose adversely affects osseointegration of titanium implants in rats. Clinical andEexperimental Dental Research., 6 (1), 107-116.

16. Dayer, R., Badoud, I., Rizzoli, R., \& Ammann, P. (2007). Defective implant osseointegration under protein undernutrition: prevention by PTH or pamidronate. Journal of Bone and Mineral Research., 22 (10), 15261533.

17. Dayer, R., Rizzoli, R., Kaelin, A., \& Ammann, P. (2006). Low protein intake is associated with impaired titanium implant osseointegration. Journal of Bone and Mineral Research., 21 (2), 258-264.

18. Dvorak, G., Fügl, A., Watzek, G., Tangl, S., Pokorny, P., \& Gruber, R. (2012). Impact of dietary vitamin D on osseointegration in the ovariectomized rat. Clinical Oral Implants Research., 23 (11), 1308-1313.

19. Fretwurst, T., Grunert, S., Woelber, J.P., Nelson, K., \& Semper-Hogg, W. (2016). Vitamin D deficiency in early implant failure: two case reports. International Journal of Implant Dentistry., 2(1), 1-6.

20. Mangano, F.G., Oskouei, S.G., Paz, A., Mangano, N., \& Mangano, C. (2018). Low serum vitamin D and early dental implant failure: Is there a connection? A retrospective clinical study on 1740 implants placed in 885 patients. Journal of Dental Research, Dental Clinics, Dental Prospects., 12 (3), 174-182.

21. Javed, F., Malmstrom, H., Kellesarian, S.V., AlKheraif, A.A., Vohra, F., \& Romanos, G.E. (2016). Efficacy of vitamin D3 supplementation on osseointegration of implants. Implant Dentistry., 25 (2), 281-287.

22. Li, X., Tang, L., Lin, Y.F., \& Xie, G.F. (2018). Role of vitamin $C$ in wound healing after dental implant surgery in patients treated with bone grafts and patients with chronic periodontitis. Clinical Implant Dentistry and Related Research., 20 (5), 793-798.

23. Baldisserotto, J., Padilha, D.M., \& Amenábar, J.M. (2019). The Influence of Dietary Salt on the Osseointegration of Implants in Aging Rats. International Archives of Otorhinolaryngology., 23 (4), 427-432.

24. Pimentel, S.P., Casarin, R.C., Ribeiro, F.V., Cirano, F.R., Rovaris, K., Haiter Neto, F., \& Casati, M.Z. (2016). Impact of micronutrients supplementation on bone repair around implants: microCT and counter-torque analysis in rats. Journal of Applied Oral Science. 24 (1), 45-51.

25. Beaudette, J.R., Fritz, P.C., Sullivan, P.J., Piccini, A., \& Ward, W.E. (2021). Patients undergoing periodontal procedures commonly use dietary supplements: A consideration in the design of intervention trials. Clinical and Experimental Dental Research,. 7 (1), 123128.

26. Flanagan, D. (2016). Diet and implant complications. Journal of Oral Implantology., 42 (3), 305-310.

27. Lau, B.Y., Johnston, B.D., Fritz, P.C., \& Ward, W.E. (2013). Dietary strategies to optimize wound healing after periodontal and dental implant surgery: an evidence-based review. The Open Dentistry Journal., 7, 36-46.

28. Najeeb, S., Zafar, M.S., Khurshid, Z., Zohaib, S., \& Almas, K. (2016). The role of nutrition in periodontal health: an update. Nutrients., 8 (9), 530. 